\title{
Thermodynamic Stability of Ettringite Formed by Hydration of Ye'elimite Clinker
}

\section{Marcela Fridrichová, Karel Dvořák, Dominik Gazdič, Jana Mokrá, and Karel Kulísek}

Brno University of Technology, Veveři 331/95, 60200 Brno, Czech Republic

Correspondence should be addressed to Karel Dvořák; dvorak.k@fce.vutbr.cz

Received 31 May 2016; Revised 29 July 2016; Accepted 16 August 2016

Academic Editor: Kestutis Baltakys

Copyright (C) 2016 Marcela Fridrichová et al. This is an open access article distributed under the Creative Commons Attribution License, which permits unrestricted use, distribution, and reproduction in any medium, provided the original work is properly cited.

In order to save limited natural resources by utilising industrial by-products, this paper focuses on an entirely new application of fluidized bed combustion fly ash (FBCFA) into Portland composite cements. It is not currently used because undesirable ettringite, $3 \mathrm{CaO} \cdot \mathrm{Al}_{2} \mathrm{O}_{3} \cdot 3 \mathrm{CaSO}_{4} \cdot 32 \mathrm{H}_{2} \mathrm{O}$, is formed during the hydration of FBCFA. Although the stability of ettringite has been the subject of much research, the solution is not yet fully clear. Ettringite is generally considered to be stable up to a temperature of $110^{\circ} \mathrm{C}$; however, some investigators claimed that ettringite may already decompose at even ambient temperatures. To prove these statements, ettringite was prepared by the hydration of yeelimite, $3 \mathrm{CaO} \cdot 3 \mathrm{Al}_{2} \mathrm{O}_{3} \cdot \mathrm{CaSO}_{4}$, and the system stored at laboratory temperature in two environments: in laboratory settings and in an environment of saturated water vapour. The mineralogical composition of ettringite was long term (up to 160 days of hydration) and was analysed by X-ray diffraction (XRD) and differential thermal analysis (DTA). The hydration of yeelimite is a relatively complex process. Only approximately $30 \%$ of ettringite was formed under laboratory conditions that appeared to gradually convert into metaettringite. Within an environment of saturated water vapour, we observed the conversion of ettringite into monosulfate. Original yeelimite was indicated as the dominant phase of both storages.

\section{Introduction}

The production of building materials currently focuses on strength values as well as lifetime and durability. Related to this, the formation of AFt phases is most often mentioned as a display of sulfate attacks upon cementitious materials. The "A" from AFt phases means $\mathrm{Al}_{2} \mathrm{O}_{3}$, the " $\mathrm{F}$ " represents $\mathrm{Fe}_{2} \mathrm{O}_{3}$, and " $\mathrm{t}$ " is an abbreviation of the numeral "three" in Latin. AFt phases are described by the formula

$$
\left[\mathrm{Ca}_{3}(\mathrm{Y})(\mathrm{OH})_{6} \cdot 12 \mathrm{H}_{2} \mathrm{O}\right] \cdot \mathrm{X}_{z} \cdot x \mathrm{H}_{2} \mathrm{O}
$$

where $\mathrm{Y}$ represents cation, most often $\mathrm{Al}^{3+}, \mathrm{Fe}^{3+}$, or $\mathrm{Cr}^{3+}, \mathrm{X}$ represents $\mathrm{CO}_{3}{ }^{2-}, \mathrm{SO}_{4}{ }^{2-}$, and less often $\mathrm{SeO}_{4}{ }^{2-}$ or $\mathrm{CrO}_{4}{ }^{2-}$, and $x \leq 2, z \leq 2$.

The term "AFt" responds to 3 molecules of $\mathrm{CX}$, and the formula can generally be written as

$$
\mathrm{C}_{3}(\mathrm{~A}, \mathrm{~F}) \cdot 3 \mathrm{CX} \cdot y \mathrm{H}_{2} \mathrm{O}
$$

where $\mathrm{C}$ represents $\mathrm{CaO}$, A represents $\mathrm{Al}_{2} \mathrm{O}_{3}$, F represents $\mathrm{Fe}_{2} \mathrm{O}_{3}$, and $y=x+30$.
Ettringite $\left(3 \mathrm{CaO} \cdot \mathrm{Al}_{2} \mathrm{O}_{3} \cdot 3 \mathrm{CaSO}_{4} \cdot 32 \mathrm{H}_{2} \mathrm{O}\right)$ is the most important representative of this group. It is a high water mineral that is primarily formed at an early period of the hydration of Portland cement. Its structure is hexagonal, with needle-like crystals [1].

Although the decomposition of ettringite has been the subject of many studies, neither accurate temperatures of decomposition nor mechanisms and kinetics of this process were clarified. Moreover, there is some discrepancy among the conclusions of various authors.

Taylor et al. [2] claim that ettringite is internally unstable at temperatures greater than $70^{\circ} \mathrm{C}$. This value is shifted upward to $90^{\circ} \mathrm{C}$ when a sufficient amount of sulfate is present.

Zhou and Glasser [3] agree with the generally valid opinion that ettringite is unstable at higher temperatures. For instance, it is less stable than hydrogarnet $\left(3 \mathrm{CaO} \cdot \mathrm{Al}_{2} \mathrm{O}_{3}\right.$. $6 \mathrm{H}_{2} \mathrm{O}$ ), which decomposes at a temperature of $325^{\circ} \mathrm{C}$. Zhou and Glasser further claim that metaettringite, the decomposed product of ettringite, is typically formed at temperature ranges between 50 and $100^{\circ} \mathrm{C}$. At temperatures of $110-114^{\circ} \mathrm{C}$, 
ettringite decomposes into calcium sulfate hemihydrate, water, and an amorphous compound that is probably AFm phase.

When the ettringite is exposed to very low values of water vapour pressures $(6 \mathrm{~mm})$, metaettringite is the primary product of decomposition but it spontaneously and gradually transforms into AFm phase.

Šatava and Vepřek [4] found a spontaneous decomposition of ettringite at a temperature of $125^{\circ} \mathrm{C}$. Certain similar results were also found by Ogawa and Roy [5] under hydrothermal conditions at temperatures over $100^{\circ} \mathrm{C}$. Hall et al. [6] claimed that ettringite begins to decompose at a water vapour pressure of $1.63 \mathrm{bar}$ (approximately $163 \mathrm{kPa}$ ) at a temperature of $114 \pm 1^{\circ} \mathrm{C}$. The study of Abo-el-enein et al. [7] determines weight losses in ettringite at temperature lower than $100^{\circ} \mathrm{C}$. Taylor [1] determines the temperature of decomposition to be $110^{\circ} \mathrm{C}$. Artificial ettringite becomes nearly amorphous, due to either higher temperature or vacuum. In an environment with ambient relative humidity, ettringite already begins to lose water molecules at $50^{\circ} \mathrm{C}$. The endotherm of ettringite from DTA analysis is located at temperatures ranging between 110 and $150^{\circ} \mathrm{C}$. When ettringite originates from cement paste, the typical peak can be found at temperatures between 125 and $130^{\circ} \mathrm{C}$.

Pourchez et al. [8] claim that ettringite may be thermally unstable at temperatures lower than $120^{\circ} \mathrm{C}$, depending on the pressure of water vapour. Decomposing ettringite forms metaettringite, containing 10-13 molecules of water, its amount depending upon time.

Zhou et al. [9] also mention temperatures of decomposition in a range between 114 and $116^{\circ} \mathrm{C}$, at water vapour pressures greater than 760 Torr (approximately $133.3 \mathrm{~Pa}$ ). In the presence of water, ettringite decomposes, forming hemihydrate, $\mathrm{CaSO}_{4} \cdot 0,5 \mathrm{H}_{2} \mathrm{O}$, water, and a compound that may be monosulfate, depending on its $\mathrm{CaO} / \mathrm{Al}_{2} \mathrm{O}_{3} / \mathrm{SO}_{3}$ ratio.

The stability of ettringite depends, among other factors, on $\mathrm{pH}$ value. According to Santhanam et al. [10], ettringite is unstable in a low-lime environment when $\mathrm{pH}$ value decreases more than 11.5-12.0. Ettringite decomposes into gypsum below this $\mathrm{pH}$ value. Shimada and Young [11] extend the stable range of ettringite $\mathrm{pH}$ value to 9.0 to 13.4.

Warren and Reardon [12] studied the stability of ettringite with respect to its solubility. They presume that ettringite dissociates according to the following reaction:

$$
\begin{aligned}
& \mathrm{Ca}_{6} \mathrm{Al}_{2} \mathrm{O}_{6}\left(\mathrm{SO}_{4}\right)_{3} \cdot 32 \mathrm{H}_{2} \mathrm{O} \\
& \longrightarrow 6 \mathrm{Ca}^{2+}+2 \mathrm{Al}(\mathrm{OH})_{4}{ }^{-}+3 \mathrm{SO}_{4}{ }^{2-}+4 \mathrm{OH}^{-} \\
&+26 \mathrm{H}_{2} \mathrm{O}
\end{aligned}
$$

Zhou and Glasser [3], as well as Hargis et al. [13, 14], claim that ye'elimite hydrates to give off monosulfoaluminate and aluminium hydroxide, as can be seen in the following reaction:

$$
\begin{aligned}
& 3 \mathrm{CaO} \cdot 3 \mathrm{Al}_{2} \mathrm{O}_{3} \cdot \mathrm{CaSO}_{4}+18 \mathrm{H}_{2} \mathrm{O} \\
& \longrightarrow 3 \mathrm{CaO} \cdot \mathrm{Al}_{2} \mathrm{O}_{3} \cdot \mathrm{CaSO}_{4} \cdot 12 \mathrm{H}_{2} \mathrm{O}+4 \mathrm{Al}(\mathrm{OH})_{3}
\end{aligned}
$$

When ye'elimite is accompanied by calcium and sulfate ions and then reacts with water, ettringite is formed; see the following reaction:

$$
\begin{aligned}
3 \mathrm{CaO} & \cdot 3 \mathrm{Al}_{2} \mathrm{O}_{3} \cdot \mathrm{CaSO}_{4}+8 \mathrm{CaSO}_{4}+6 \mathrm{Ca}(\mathrm{OH})_{2} \\
& +90 \mathrm{H}_{2} \mathrm{O} \\
\longrightarrow & 3\left(3 \mathrm{CaO} \cdot \mathrm{Al}_{2} \mathrm{O}_{3} \cdot 3 \mathrm{CaSO}_{4} \cdot 32 \mathrm{H}_{2} \mathrm{O}\right)
\end{aligned}
$$

When gypsum is depleted, formations of monosulfate become dominant. Fridrichová et al. [15] probably performed the latest experiment that synthesised ettringite by a procedure involving the direct hydration of mineral yeelimite $\left(3 \mathrm{CaO} \cdot 3 \mathrm{Al}_{2} \mathrm{O}_{3} \cdot \mathrm{CaSO}_{4}\right)$ for 28 days at laboratory temperatures. However, the long-term stability of this ettringite has not yet been fully described. Based on the above-mentioned facts, because of its low temperature of decomposition and high content of relatively free bonded water, we can presume that ettringite will gradually decompose due to the evaporation of free bonded water under dry conditions and be more stable in conditions of higher humidity.

The aim of this paper is to describe the long-term stability of ettringite formed by yeelimite clinker hydration under conditions of varying humidity.

\section{Materials and Methods}

In order to observe the long-term thermodynamic stability of ettringite, it was prepared by the hydration of yeelimite clinker, $3 \mathrm{CaO} \cdot 3 \mathrm{Al}_{2} \mathrm{O}_{3} \cdot \mathrm{CaSO}_{4}$. Samples of hydrated ye'elimite clinker were next exposed to two varied conditions.

The raw meal for yeelimite clinker preparation consisted of 3 compounds: limestone $\mathrm{CaCO}_{3}$ with a purity of $99 \%$, corundum $\mathrm{Al}_{2} \mathrm{O}_{3}$ with a purity of $100 \%$, and gypsum $\mathrm{CaSO}_{4} \cdot 2 \mathrm{H}_{2} \mathrm{O}$ with a purity of $98.6 \%$. Their ratios were calculated according to the stoichiometric ratio of yeelimite. The raw meal then contained 38.44\% limestone, 39.21\% corundum, and $22.35 \%$ gypsum. The three components were homogenized and milled under wet conditions in a Planetary Mono Mill PULVERISETTE 6. The volume of the capsule was $500 \mathrm{~mL}$ and the size of milling bodies was $20 \mathrm{~mm}$. Isopropyl alcohol was chosen as the inert liquid for milling and homogenization. Milling and homogenization were carried out gradually, in $200 \mathrm{~g}$ doses at $500 \mathrm{rpm}$ for $15 \mathrm{~min}$. The individual doses were next blended, using an electric blender. The resulting mixture was then dried in a laboratory drier at a temperature of $50^{\circ} \mathrm{C}$ for $24 \mathrm{~h} .3 \mathrm{~kg}$ of raw meal was prepared in total.

The raw meal was then placed into $30 \mathrm{~mL}$ platinum crucibles and compacted by stomping. A $4 \mathrm{~mm}$ diameter cavity was made in the centre of the material to enable the easy release of gas. The firing process was performed in a classic 1700 kiln at a temperature of $1200^{\circ} \mathrm{C}$, soaking for $3 \mathrm{~h}$, and a heating rate of $10^{\circ} \mathrm{C} / \mathrm{min}$. The firing process was subsequently terminated by quenching, using pressurized air.

The resulting clinker was then ground in a planetary mill under dry conditions at $300 \mathrm{rpm}$, allowing no particles larger than $0.063 \mathrm{~mm}$ at completion. Prior to that, the sample for the powder diffraction was refined, using a McCrone 
Micronising Mill for $150 \mathrm{~s}$. The mineralogical composition of the ye'elimite clinker was examined by XRD analysis using a Panalytical Empyrean diffractometer (copper anode $\lambda \mathrm{K}_{\alpha 1}=$ $1.54056 \AA$ generated at $45 \mathrm{~mA}$ and $40 \mathrm{kV}$ ). The measurement step size was $0.013^{\circ} 2 \theta$ with integration at the rate of $150 \mathrm{~s}$ per step. The high score+ analysis was used for XRD pattern assessments.

The ye'elimite clinker was hydrated, becoming paste. The water/clinker ratio of 0.55 was chosen to prevent hydration pauses due to lack of water. $10 \times 10 \times 30 \mathrm{~mm}$ prisms were manufactured in order to easily manipulate the hydrated paste. During the initial 24 hours, samples were stored under damp conditions, $\mathrm{RH}>90 \%$ and a temperature of $21^{\circ} \mathrm{C}$. Following that, the samples were demoulded and were stored under two conditions:

(i) laboratory conditions, temperature of $21^{\circ} \mathrm{C}$ and $\mathrm{RH}$ of $40 \%$,

(ii) an environment of saturated water vapour at a temperature of $21^{\circ} \mathrm{C}$.

In order to observe the process of hydration, three samples for XRD analysis as well as for DTA were taken from both conditions twice a week up to a hydration age of 160 days. For all analyses, hydrated yeelimite samples were first crushed in an agate bowl and hydration was stopped by triple washing in isopropyl alcohol. The material was subsequently refined using a McCrone Micronising Mill for $150 \mathrm{~s}$ (also in isopropyl alcohol). Following those procedures, the samples were gently dried at $30^{\circ} \mathrm{C}$ in a laboratory drier and analysed. DTA were performed using a Mettler Toledo TG/DSC1 with a temperature range up to $1000^{\circ} \mathrm{C}$. Approximately $50-70 \mathrm{mg}$ of the sample was analysed. Average values of the three DTA measurements were used for the quantification of the ettringite and the calcium monosulfoaluminate hydrate.

For the XRD analysis, the same settings were used as in the previous case.

Apart from phase composition, the $\mathrm{pH}$ value of the samples was observed once a week. One prism of each sample was weighed and ground in an agate bowl. Next, the powder was mixed with an equal weight of distilled water. This mixture was filtered after 24 hours and the $\mathrm{pH}$ of the solution was measured using an electronic $\mathrm{pH}$-meter Mettler Toledo Easy 21. The $\mathrm{pH}$ of the hydrated pastes under both storage conditions was between 9.5 and 10. For this reason, the influence of the $\mathrm{pH}$ value on the stability of ettringite was not taken into account.

\section{Results and Discussion}

3.1. Phase Composition of Ye'elimite Clinker. The results of the phase and mineralogical composition of ye'elimite clinker immediately after firing can be seen in Figure 1.

Yeelimite $(\mathrm{Y}), 3 \mathrm{CaO} \cdot 3 \mathrm{Al}_{2} \mathrm{O}_{3} \cdot \mathrm{CaSO}_{4}$ (d-spacing $=3.758$, $2.169,2.657 \AA$ Á), was identified as virtually the only mineral. Besides that, residua from precursor minerals of raw materials were slightly present, namely, anhydrite II (A), $\mathrm{CaSO}_{4}$

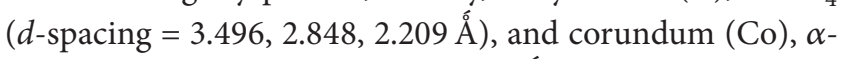

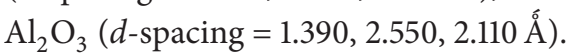

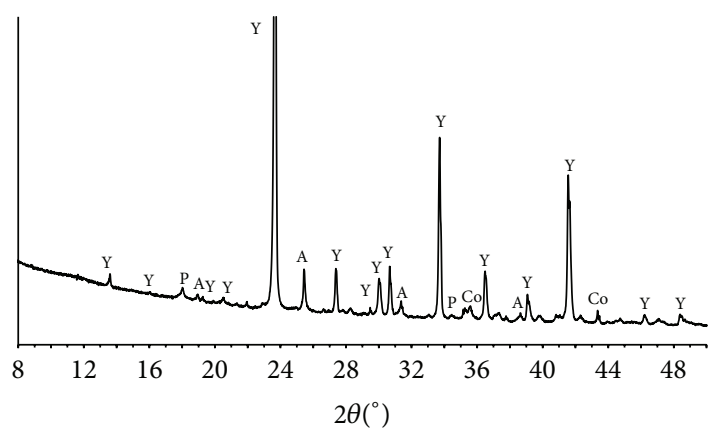

$$
\begin{array}{cl}
\text { Y: ye'elimite } & \text { P: portlandite } \\
\text { A: anhydrite } & \text { Co: corundum }
\end{array}
$$

FIGURE 1: XRD pattern of yeelimite clinker.

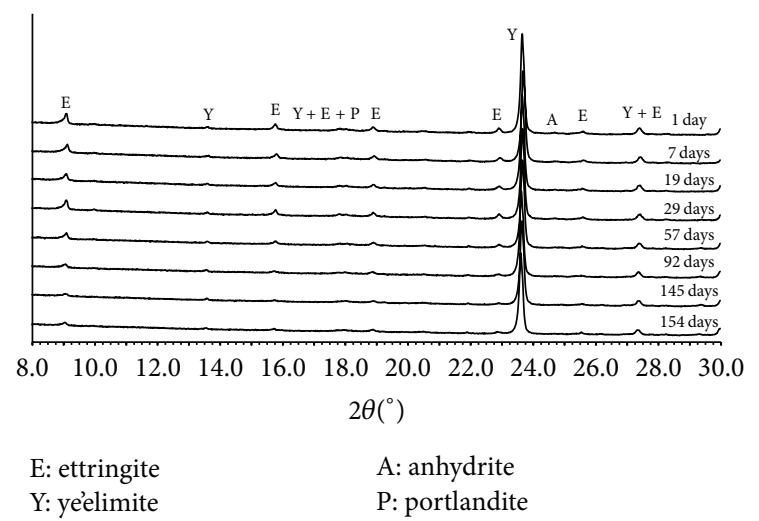

FIGURE 2: XRD patterns of hydrated ye'elimite clinker exposed to laboratory settings, age 1-159 days of hydration.

Very weak diffraction lines corresponded to portlandite

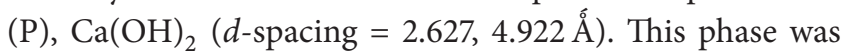
present in the XRD pattern due to the hydration of a very small amount of free lime by air humidity during XRD analysis, when the sample was stored in the sample changer magazine.

Thus, it can be claimed that raw meal components were nearly completely synthesised for yeelimite during firing.

3.2. Phase Composition of Hydrated Ye'elimite Clinker. Samples of hydrated ye'elimite clinker from laboratory conditions and environment of saturated water vapour were regularly analysed by XRD analysis and DTA analysis.

3.2.1. Phase Analysis. Figures 2 and 3 show XRD patterns of hydrated yeelimite from both storage conditions. In order to obtain a clear overview, only patterns of hydrated ye'elimite aged $1,7,19,29,57,92,145$, and 159 days are presented.

Yeelimite $(\mathrm{Y})$ and ettringite $(\mathrm{E})(d$-spacing $=9.720$, $5.610 \AA ̊$ ) were identified in XRD patterns of the samples exposed to laboratory conditions.

Except for those minerals mentioned above, calcium monosulfoaluminate hydrate $\left(\mathrm{M}_{1}\right), 3 \mathrm{CaO} \cdot \mathrm{Al}_{2} \mathrm{O}_{3} \cdot \mathrm{CaSO}_{4}$.

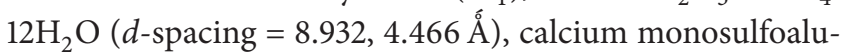




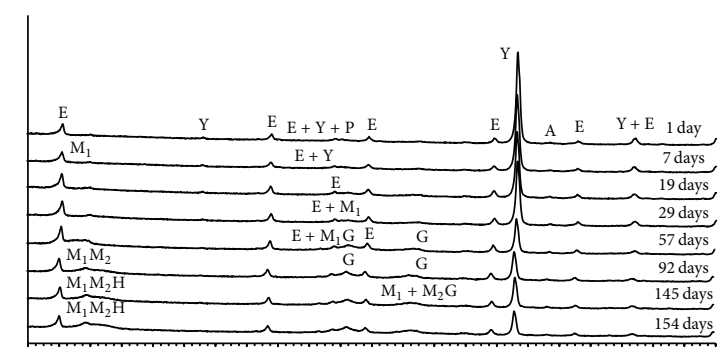

$\begin{array}{llllllllllll}8.0 & 10.0 & 12.0 & 14.0 & 16.0 & 18.0 & 20.0 & 22.0 & 24.0 & 26.0 & 28.0 & 30.0\end{array}$ $2 \theta\left(^{\circ}\right)$

$\begin{array}{ll}\text { E: ettringite } & \mathrm{H}: \mathrm{C}_{4} \mathrm{AH}_{\mathrm{X}} \\ \text { Y: ye'elimite } & \mathrm{G}: \text { Gibbsite } \\ \mathrm{M}_{1} \text { : monosulfate- } 12 \mathrm{H}_{2} \mathrm{O} & \mathrm{A} \text { : anhydrite } \\ \mathrm{M}_{2} \text { : monosulfate- } 11 \mathrm{H}_{2} \mathrm{O} & \mathrm{P} \text { : portlandite }\end{array}$

FIGURE 3: XRD patterns of hydrated ye'elimite clinker exposed to environment of saturated water vapour, aged 1-159 days of hydration.

minate hydrate $\left(\mathrm{M}_{2}\right), 3 \mathrm{CaO} \cdot \mathrm{Al}_{2} \mathrm{O}_{3} \cdot \mathrm{CaSO}_{4} \cdot 11 \mathrm{H}_{2} \mathrm{O}$ (d-spacing

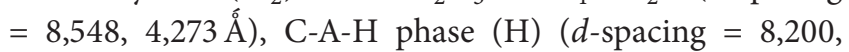
$2,860)$, and possibly Gibbsite $(\mathrm{G}) \mathrm{Al}(\mathrm{OH})_{3}$ (d-spacing = $4,850,4,350$ ) were identified in XRD patterns in the case of the samples exposed to an environment of saturated water vapour. Residua of minerals from the original raw materials were rarely found either. However, these negligible contents did not affect the observed processes.

In early stages of hydration under laboratory conditions, hydrated samples showed a high intensity of the diffraction lines of the original yeelimite and a comparatively low intensity of resulting ettringite. No growth of ettringite diffraction lines was noticed during early stage hydration under laboratory conditions.

Conversely, its intensity apparently decreases under longterm observation. We claim that this effect was associated with the drying of ettringite, that is, the loss of relatively free bonded water molecules from its structural cavities. As no other crystalline phases or products of hydration were detected during ye'elimite hydration under laboratory settings, it confirms the opinion according to [3] that the loss of molecular water results in the transformation of crystalline ettringite into an amorphous substance, designated in literature as a metaettringite [9].

In the environment of saturated water vapour, the gradual increase of intensity of ettringite diffraction and corresponding decrease of yeelimite diffraction were observed up to approximately 60 days of hydration. A marked release of basal diffraction of monosulfate $\left(M_{1}\right)$, initially with a very diffuse character, was observed between 15 and 20 days of hydration, as can be seen in Figure 3.

Over the course of time, the intensity and sharpness of this diffraction rose and other types of diffraction of monosulfate became apparent. With increasing intensities of monosulfate, the intensity of diffraction of ettringite virtually stopped. This means ettringite is not the only hydration product of yeelimite. Monosulfate is also formed, which has the same stoichiometric ratio of $\mathrm{CaO} / \mathrm{SO}_{3}$ as that of ye'elimite.

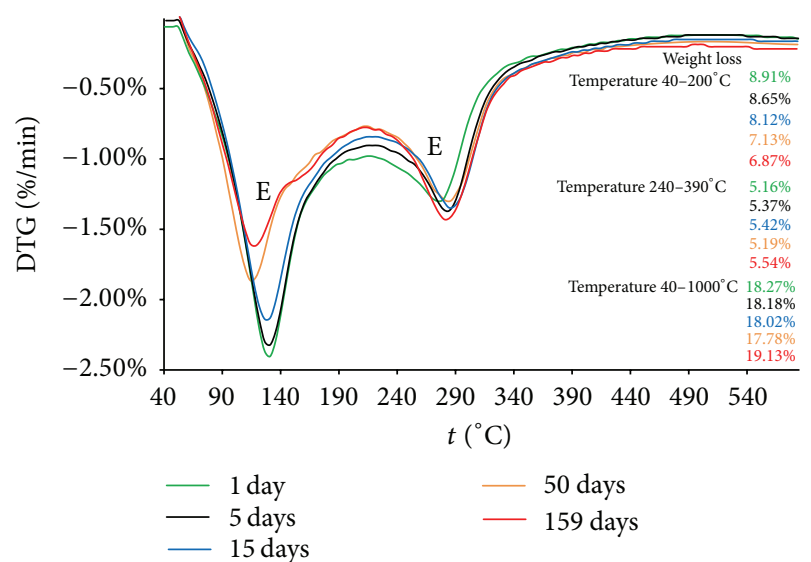

FIGURE 4: DTA of hydrated ye'elimite clinker exposed to laboratory conditions $(\mathrm{E}=$ ettringite $)$.

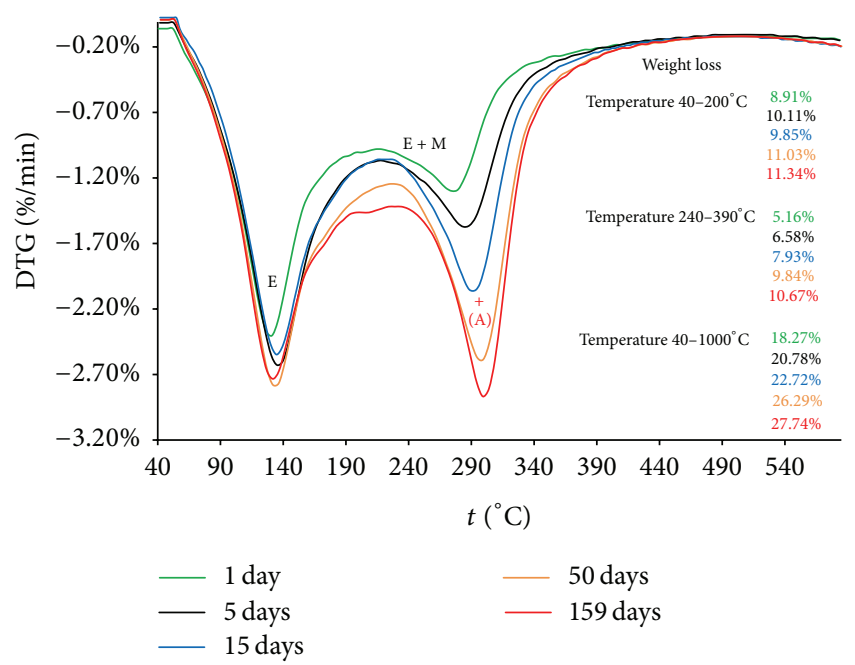

FIGURE 5: DTA analysis of hydrated ye'elimite clinker exposed to environment of saturated water vapour ( $E$ is ettringite, $M$ is calcium monosulfoaluminate hydrate, and $\mathrm{A}$ is calcium aluminate hydrate phases).

Thus, it can be assumed that monosulfate will prevail in the system over long-term storage in an environment of saturated water vapour. For that reason, ettringite will also gradually transform into it.

Over approximately 60 days, very diffuse diffraction lines of Gibbsite were identified and later, after 150 days of hydration, also $\mathrm{C}_{4} \mathrm{AH}_{X}$ as a representative of $\mathrm{C}-\mathrm{A}-\mathrm{H}$ phases was found. All these findings correspond to $[3,13,14]$. According to [10, 11], gypsum was not identified in any cases. Nevertheless, this fact should be verified in follow-up research.

3.2.2. DTA and the Quantification of Hydration Products. Figures 4 and 5 present DTA analysis curves of hydrated yeelimite from the laboratory settings and environment of saturated water vapour. In order to obtain a clear overview and better resolution, only curves of hydrated yeelimite at 
ages $1,5,15,50$, and 159 days and temperatures up to $600^{\circ} \mathrm{C}$ are presented in the graphs.

The first endothermic effect in the temperature ranges of $40-200^{\circ} \mathrm{C}$ corresponds to the loss of molecular water from ettringite. The second effect, at $240-390^{\circ} \mathrm{C}$, represents the losses of water arising from dehydration of calcium monosulfoaluminate hydrate, assuming the monosulfate has been presented in the sample [1]. However, the same second effect is also presented in the typical DTA of a pure ettringite curve [1]. In this case, this effect may correspond to a loss of the rest of molecular water and hydroxyl water from the ettringite.

Total loss of annealing, at temperatures of 40 to $1000^{\circ} \mathrm{C}$, was always about 4 to $6.5 \%$ higher than the loss of annealing in the observed temperature range from 40 to $390^{\circ} \mathrm{C}$. In the complete DTA curves, the endothermic effect of about $750^{\circ}$ to $790^{\circ} \mathrm{C}$ occurred in addition to the endothermic effects in the range of 40 to $390^{\circ} \mathrm{C}$. The data is presented in Figures 4 and 5 .

This effect corresponded to the decomposition of calcium carbonate. The carbonate formed in the samples due to the hydration and subsequent carbonation of free lime from clinker. However, the content of this phase was not substantial enough for the study of the issue of quantifying the content of ettringite and monosulfate.

Upon storage in a laboratory environment, the loss of ignition ratios between the first and second endothermic effect decreased with the period of hydration. Because, according to $\mathrm{XRD}$ analysis results, monosulfate is not present in the samples (or its amount is below the method's detection threshold), this phenomenon may be explained as a consequence of the gradual evaporation of molecular water, related to the transformation of ettringite into metaettringite [8]. On the contrary, upon storage in an environment saturated with water vapours, this effect cannot occur. Thus, in this case, the ratio of loss of annealing between the first and second endotherm for the hydration time period of one day was used to quantify monosulfate in the presence of ettringite, where only ettringite was actually present in the sample.

Thus, the established ratio of the overall loss by annealing under the second endoeffect was subtracted from the overall annealing loss that corresponds to the decomposition of ettringite in samples stored in an environment saturated with water vapours. The remaining loss by annealing under the second endoeffect was then attributed to the decomposition of monosulfate. Upon long-term hydration in this environment, there was also an initial development of the C-A$\mathrm{H}$ phases of the $\mathrm{C}_{4} \mathrm{AH}_{X}$ type. The eventual development of Gibbsite was observed from approximately day 150 on. The presence of these phases was disregarded during the quantification of these monosulfates.

(1) Laboratory Conditions-Quantification. In consideration of the absence of other hydration products, it was possible to quantify the amount of ettringite that was produced due to hydration of yeelimite clinker stored under laboratory conditions; see Figure 6.

Amounts of the ettringite decreased slightly, but gradually, when stored under laboratory conditions. This statement corresponds very well to the results of XRD analysis. In order

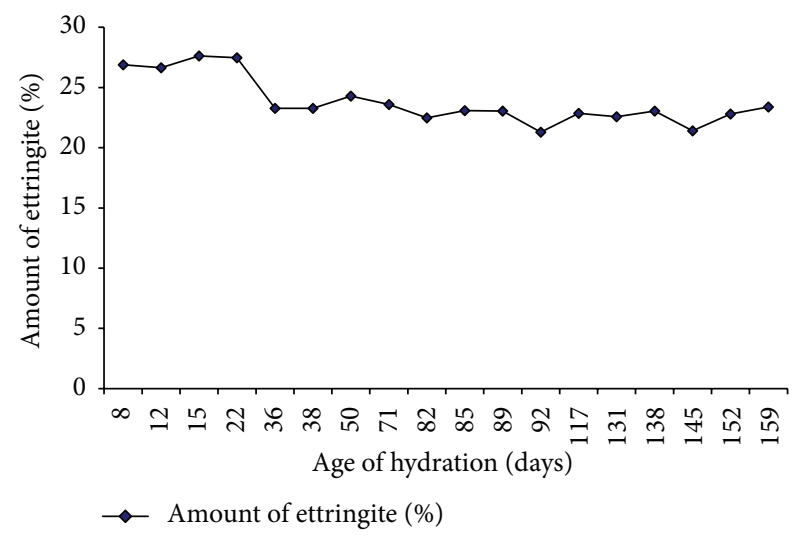

FIgURE 6: Average amount of ettringite in hydrated ye'elimite clinker exposed to laboratory conditions.

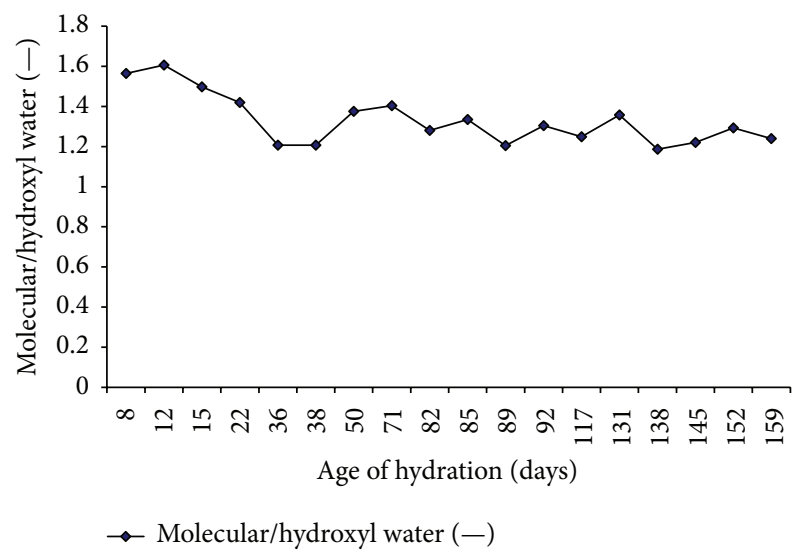

FIGURE 7: Molecular water to hydroxyl water ratio of hydrated ye'elimite clinker exposed to laboratory conditions.

to verify the gradual loss of molecular water hypothesis, the loss of water ratios between the first (molecular water) and the second (hydroxyl water or possibly the remainder of molecular water) endotherm was calculated for all the hydration ages; see Figure 7.

It follows that molecular water to hydroxyl water ratio gradually decreased under these laboratory conditions. This finding is consistent with the hypothesis [8] that there is a slight but progressive loss of molecular water located in the structural cavities of ettringite during hydration during their exposure under laboratory conditions. Due to this phenomenon, the conversion of ettringite into amorphous metaettringite occurs.

(2) Environment of Saturated Water Vapour-Quantification. Contrary to the yeelimite clinker hydration behaviour in laboratory conditions, the hydration of yeelimite in an environment of saturated water vapour performed differently. Based on the results from DTA, it is obvious that the amount of ettringite gradually increased up to 50 days of hydration. Monosulfate was simultaneously formed and its content achieved approximately $10 \%$ of the whole volume at the end 


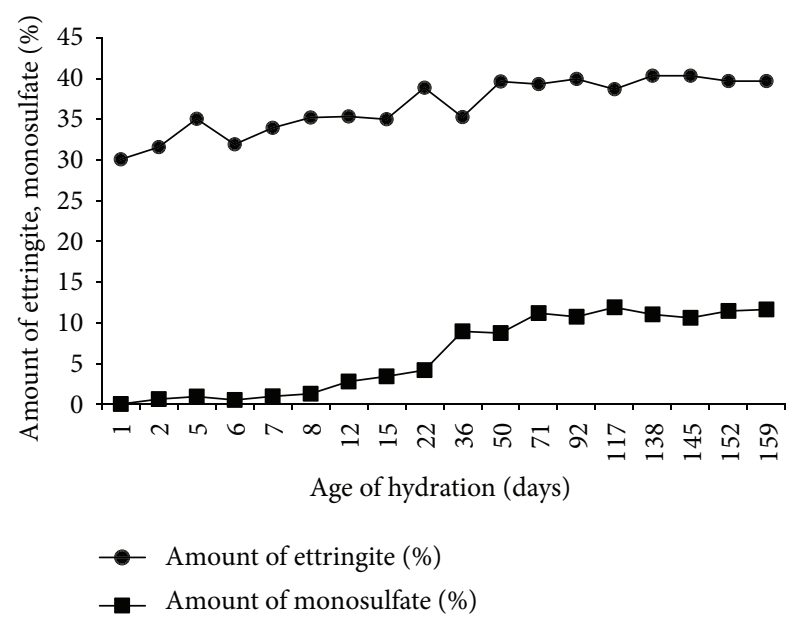

FIGURE 8: Average amount of ettringite and monosulfate in hydrated ye'elimite clinker exposed to environment of saturated water vapour.

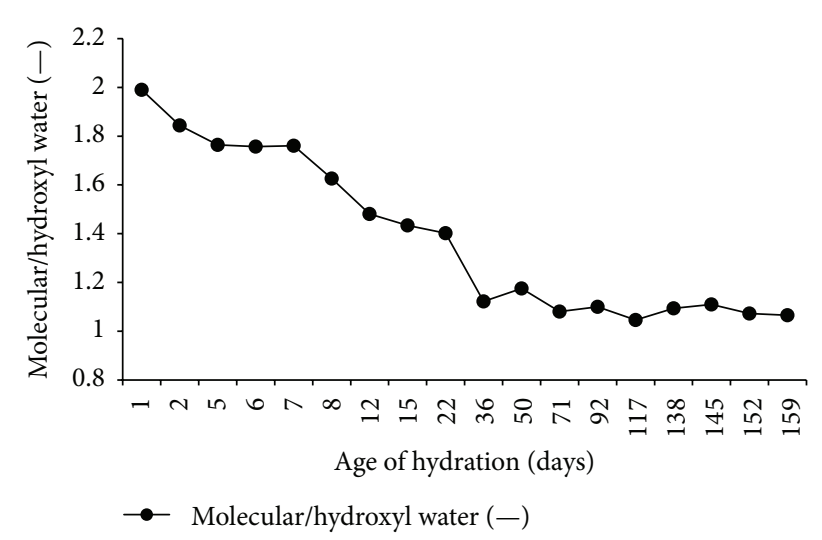

FIGURE 9: Molecular water to hydroxyl water ratio of hydrated ye'elimite clinker exposed to environment of saturated water vapour.

of the observed hydration period. This content accounted for about one-quarter of the amount of ettringite; see Figure 8.

The molecular water to hydroxyl water ratio was also reduced, as well as in the case of hydration under laboratory conditions. This was due to the formation of monosulfate in this case, as can be seen in Figure 9. The results of thermal analysis agreed very well with those of XRD analysis.

\section{Conclusion}

The stability of ettringite that was formed by the hydration of yeelimite clinker was in the study of this paper. Two conditions, with different relative humidity, were chosen for this experiment.

Under laboratory conditions, the transformation of yeelimite into ettringite was due to a deficiency of water when gradually suppressed. Due to the drying process, even the very slow but obvious conversion of crystalline ettringite into amorphous metaettringite took place in terms of later hydration periods. An increasing loss of free bonded molecular water, located in the structural cavities of ettringite, proved this transformation of ettringite into metaettringite. Even so, the hydroxyl water molecules still remained in structural units of metaettringite.

Under exposure to an environment of saturated water vapour, the content of the resulting ettringite increased, but calcium monosulfoaluminate hydrate was also formed beside ettringite in terms of relatively early periods of hydration. The maximum amount of ettringite was achieved at a hydration age of 50 days. This content did not change later, or its increase was negligible. Amounts of monosulfate were kept at relatively low levels up to an exposure of 20 days. After that, it began to grow fairly steeply. Free bonded molecular water to hydroxyl water ratios also decreased, simultaneously with increasing monosulfate content.

It is apparent from the information above that ettringite in the system of hydrated yeelimite clinker was relatively unstable in regard to both humidity conditions and the storage time periods.

\section{Competing Interests}

The authors declare that they have no competing interests.

\section{Acknowledgments}

This work was financially supported by Project no. 14-32942S "Effect of Fluidized Bed Ash on the Thermodynamic Stability of Hydraulic Binders." This paper was also developed with the financial support of Project no. LO1408 "AdMaS UPAdvanced Materials, Structures and Technologies," supported by the Czech Ministry of Education, Youth and Sports under "National Sustainability Programme I."

\section{References}

[1] H. F. W. Taylor, Cement Chemistry, Thomas Telford, London, UK, 1997.

[2] H. F. W. Taylor, C. Famy, and K. L. Scrivener, "Delayed ettringite formation," Cement and Concrete Research, vol. 31, no. 5, pp. 683-693, 2001.

[3] Q. Zhou and F. P. Glasser, "Thermal stability and decomposition mechanisms of ettringite at $<120^{\circ} \mathrm{C}$," Cement and Concrete Research, vol. 31, pp. 1333-1339, 2001.

[4] V. Šatava and O. Vepřek, "Thermal decomposition of ettringite under hydrothermal conditions," Journal of the American Ceramic Society, vol. 58, no. 7-8, pp. 357-359, 1975.

[5] K. Ogawa and D. M. Roy, " $\mathrm{C}_{4} \mathrm{~A}_{3} \mathrm{~S}$ hydration ettringite formation, and its expansion mechanism: I. expansion; ettringite stability," Cement and Concrete Research, vol. 11, no. 5-6, pp. 741750, 1981.

[6] C. Hall, P. Barnes, A. D. Billimore, A. C. Jupe, and X. Turrillas, "Thermal decomposition of ettringite $\mathrm{Ca}_{6}\left[\mathrm{Al}(\mathrm{OH})_{6}\right]_{2}\left(\mathrm{SO}_{4}\right)_{3}$. $26 \mathrm{H}_{2} \mathrm{O}$," Journal of the Chemical Society, vol. 92, no. 12, pp. 21252129, 1996.

[7] S. A. Abo-el-enein, S. Hanafi, and E. E. Hekal, "Thermal and physiochemical studies on ettringite: II. Dehydration and thermal stability," Cemento, vol. 85, no. 2, pp. 121-132, 1988 (Italian).

[8] J. Pourchez, F. Valdivieso, P. Grosseau, R. Guyonnet, and B. Guilhot, "Kinetic modelling of the thermal decomposition of 
ettringite into metaettringite," Cement and Concrete Research, vol. 36, no. 11, pp. 2054-2060, 2006.

[9] Q. Zhou, E. E. Lachowski, and F. P. Glasser, "Metaettringite, a decomposition product of ettringite," Cement and Concrete Research, vol. 34, no. 4, pp. 703-710, 2004.

[10] M. Santhanam, M. D. Cohen, and J. Olek, "Sulfate attack research-whither now?" Cement and Concrete Research, vol. 31, no. 6, pp. 845-851, 2001.

[11] Y. Shimada and J. F. Young, "Thermal stability of ettringite in alkaline solutions at $80^{\circ} \mathrm{C}$," Cement and Concrete Research, vol. 34, no. 12, pp. 2261-2268, 2004.

[12] C. J. Warren and E. J. Reardon, "The solubility of ettringite at $25^{\circ}$ C, 'Cement and Concrete Research, vol. 24, no. 8, pp. 15151524, 1994.

[13] C. W. Hargis, A. P. Kirchheim, P. J. M. Monteiro, and E. M. Gartner, "Early age hydration of calcium sulfoaluminate (synthetic ye'elimite, $\mathrm{C}_{4} \mathrm{~A}_{3} \bar{S}$ ) in the presence of gypsum and varying amounts of calcium hydroxide," Cement and Concrete Research, vol. 48, pp. 105-115, 2013.

[14] C. W. Hargis, A. Telesca, and P. J. M. Monteiro, "Calcium sulfoaluminate (Ye'elimite) hydration in the presence of gypsum, calcite, and vaterite," Cement and Concrete Research, vol. 65, pp. 15-20, 2014.

[15] M. Fridrichová, K. Dvořák, K. Kulísek, A. Masárová, and K. Havlíčková, "Synthetic preparation of ettringite," Advanced Materials Research, vol. 1000, pp. 55-58, 2014. 

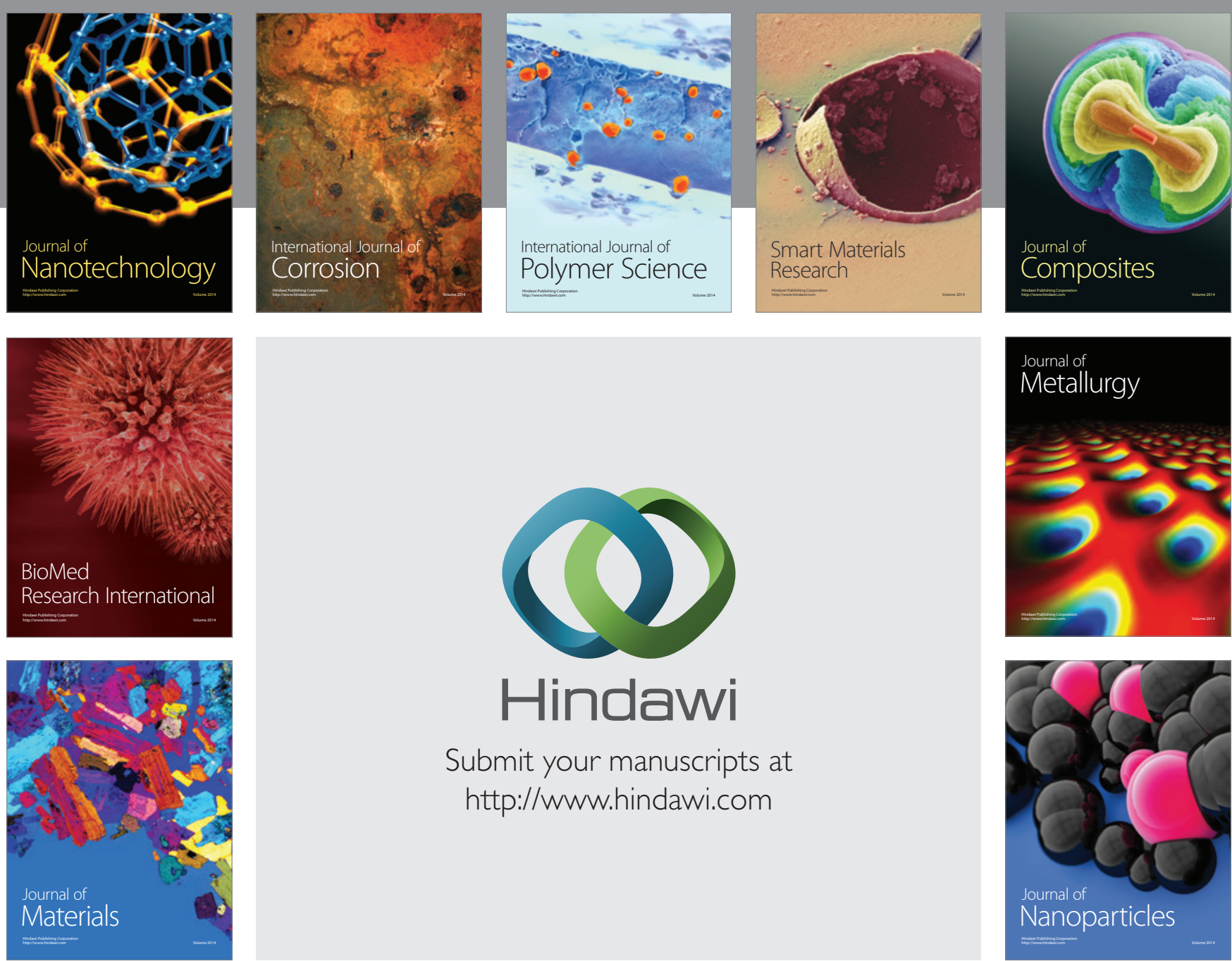

\section{Hindawi}

Submit your manuscripts at

http://www.hindawi.com

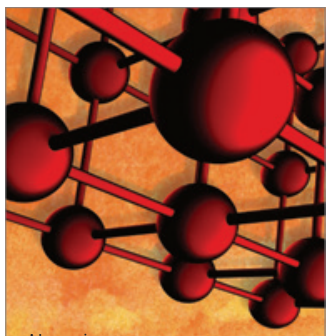

Materials Science and Engineering
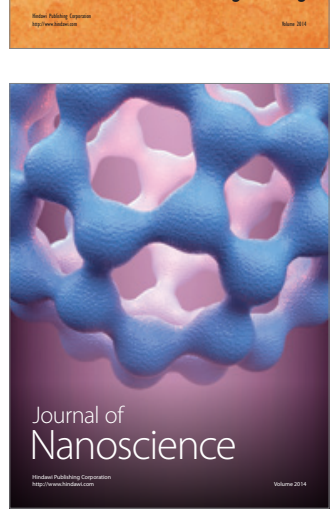
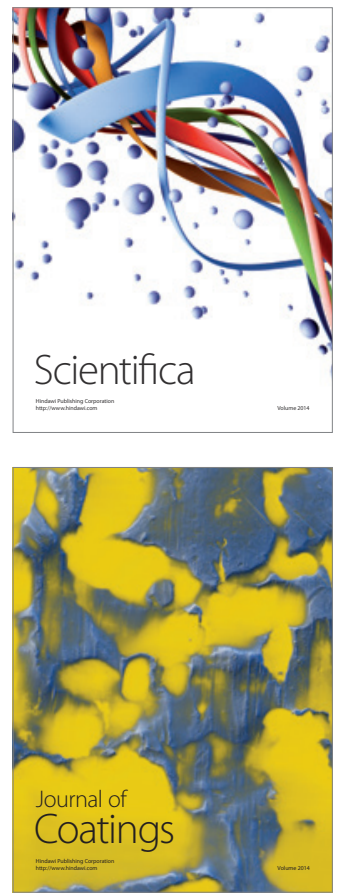
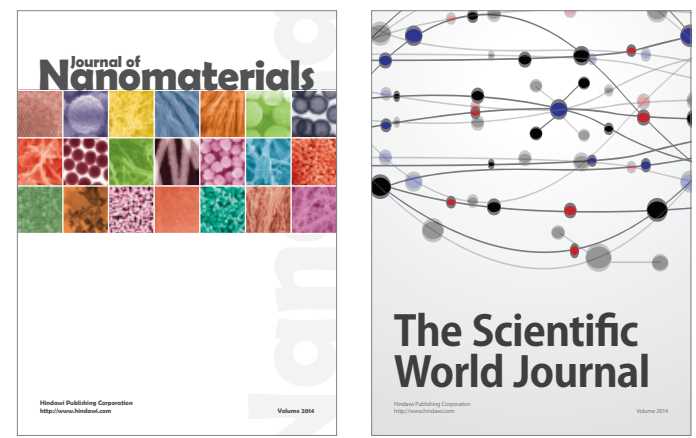

The Scientific World Journal
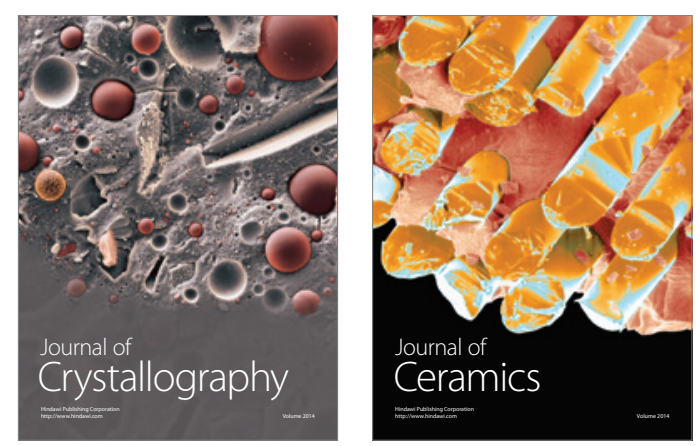
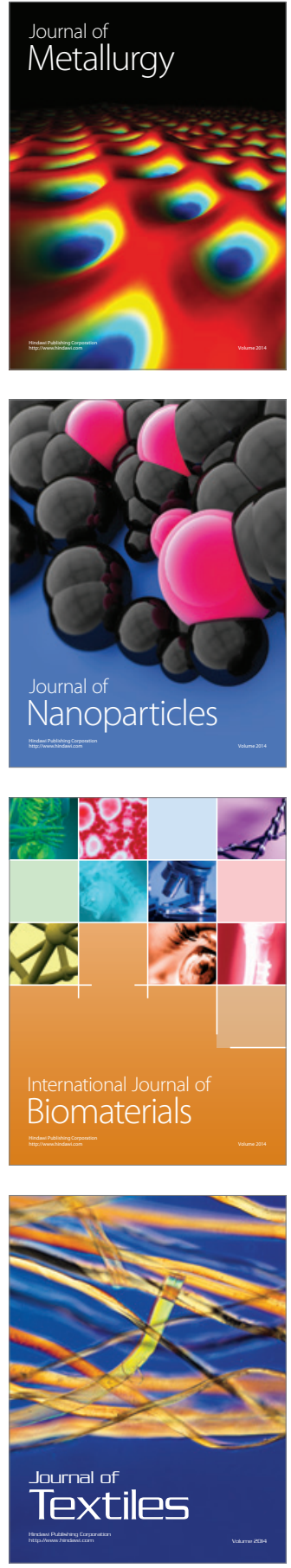